$\xi=$

\title{
The Effects of Myo-Inositol and Indole Butyric Acid (IBA) on the Formation of In Vitro Pineapples Root (Ananas comosus L.) from Sipahutar North Sumatera Indonesia
}

\author{
Arisah Hasanah $^{1}$, Fauziyah Harahap ${ }^{2}$, Ramlan Silaban ${ }^{3}$ \\ ${ }^{1}$ Postgraduate Program of Biology Department, Faculty of Mathematics and Natural Sciences, Universitas Negeri Medan, Jl. Willem \\ Iskandar Psr V Medan Estate, Indonesia \\ ${ }^{2}$ Biology Department, Faculty of Mathematics and Natural Sciences, Universitas Negeri Medan, Jl. Willem Iskandar Psr V Medan, \\ Sumatera Utara 20221, Indonesia. Telp.(061)6613365. Fax. (061)6614002 / 6613319 \\ ${ }^{3}$ Chemistry Department, Faculty of Mathematics and Natural Sciences, Universitas Negeri Medan, Jl. Willem Iskandar Psr V Medan, \\ Sumatera Utara 20221, Indonesia. Telp.(061)6613365. Fax. (061)6614002 / 6613319 \\ *Corresponding author E-mail: fauziyahharahap@unimed.ac.id
}

\begin{abstract}
Background: Rooting of in vitro pineapple from Sipahutar is an alternative to obtain superior seeds in large quantities to meet the needs of farmers and consumers.

Objective: The purpose of this study was to investigate the effect of Myo-inositol and IBA on pineapple rooting in vitro (Ananas comosus L.) from Sipahutar.

Methods: The research method used a completely randomized factorial design with two factors: Factor I: Myo-inositol consisted of 4 treatment concentrations: $\mathrm{M} 0=0 \mathrm{gr} / \mathrm{l}, \mathrm{M} 0.02=0.02 \mathrm{gr} / \mathrm{l}, \mathrm{M} 0.04=0.04 \mathrm{gr} / \mathrm{l}, \mathrm{M} 0.06=0.06 \mathrm{gr} / \mathrm{l}$. Factor II: IBA growth regulators consisted of 3 treatment concentrations: IB0 $=0 \mathrm{ppm}, \mathrm{IB} 1.5=1.5 \mathrm{ppm}, \mathrm{IB} 3=3 \mathrm{ppm}$. The parameters observed were time of root emergence, number of roots, number of leaves, time of leaf emergence, number of tillers, and time of its emergence observed each week, while the height of tillers, shoots, and whole shoots, root length, leaf width and leaf length were observed 12 weeks after planting (WAP).

Results: The result of the research showed that root time appeared on 3 WAP. The increasing number of leaves and timing of the puppiesin 1 WAP. Myo-inositol had significant effects on root counts in the $0.06 \mathrm{gr} / \mathrm{l}$ and root length on Myo-inositol treatment in the 0.04 $\mathrm{gr} / \mathrm{l}$. IBA did not have a real effect on the entire observation parameters. The interactions of Myo-inositol and IBA had significant effects on root number, number of leaves, leaf length and tiller height.

Conclusions: Myo-inositol and IBA had significant effects on root number, leaf number, leaf length and shoot height of pineapple's explant from Sipahutar.
\end{abstract}

Keywords: Root Formation; IBA; Myo-Inositol; Ananas comosus L.; in vitro

\section{Introduction}

Pineapple (Ananas comosus L.) is one of the commodities of horticultural crops that have been developed by people in North Tapanuli Regency, North Sumatera for generations (Harahap, 2013 \& Harahap, 2015). Pineapple farming is growing after companies have been producing and exporting canned pineapple fruit that has operated in North Tapanuli (Anonymous, 2007). The total area of pineapple farming in northern Tapanuli is 25,303 hectares, with total production of 148,135 tons with productivity of 5.85 tons per hectare (Anonymous, 2016). Pineapple from Sipahutar is a source of income for the people of North Tapanuli. Pineapple fruit contains sugar (12\%) and acids $(0.6 \%)$ and sources of enriched vitamins (A, B especially thiamine, and C) and minerals (calcium, potassium, phosphorus); and iron) (Gama, 2015).

Pineapple is a tropical fruit that has economic value with many health benefits (Duval et al., 2001). The fruit is considered an exotic fruit, used for dessert because of its appealing taste and much nutritional value (Idowu et al., 2014). Pineapple is generally consumed as fresh fruit or processed into canned fruit. Pineapple from Sipahutar is well-known for its sweet taste and great fruit weight so that people love this pineapple (Harahap, 2013). However, there is a problem faced, that is pineapple growers in northern Tapanuli require the seeds (Anonymous, 2015). Fruit production should be balanced with the availability of seeds to meet consumer needs (Sari, 2015). To obtain high yielding seeds in large quantities can be done with in vitro culture techniques (Harahap, 2011). One of the signs of in vitro culture success is marked by root growth (Febriyanti, 2017). The formation of good roots in plantlets bound to nutrients contained in the media, nutrients will be mutually filling during the growth process in vitro (Inayah, 2015).

The objective of this study is to find out the effects of Myoinositol and Indole Butyric Acid (IBA) on the root formation of Sipahutar Pineapple in Vitro.

\section{Materials and Methods}

This research was conducted in YAHDI tissue culture laboratory, Perum Pelabuhan Jl. Lambung No. 18 Tanah 600 Medan Marelan. 
The devices used were Laminar Air Flow Cabinet (LAFC), Autoclave, Analytical Scales, Refrigerators and other standard devices of tissue culture. The material used was Sipahutar Pineapple Eksplant developed in Yahdi Laboratory of Tissue Culture, Medan. In this research, a randomized factorial design experiment with 12 treatments was used, with the basic media of MS + BAP in $1 \mathrm{ppm}$. The factors in this research were Factor I: Myo inositol consisted of 4 treatment levels: M0 $=0 \mathrm{gr} / \mathrm{l}, \mathrm{M} 0.02=0.02 \mathrm{gr} / \mathrm{l}, \mathrm{M} 0.04=$ $0.04 \mathrm{gr} / \mathrm{l}, \mathrm{M} 0.06=0.06 \mathrm{gr} / \mathrm{l}$. Factor II: IBA consisted of 3 treatment levels: IB0 $=0 \mathrm{ppm}, \mathrm{IB} 1.5=1.5 \mathrm{ppm}, \mathrm{IB} 3=3 \mathrm{ppm}$. Each treatment was replicated for 3 times, so the treatment and replica-

tion amounted to 36 bottles. The parameters observed were time of root emergence, number of root, time of leaf emergence, number of leaves, number of buds, time of buds, while the observation parameter of root length, leaf width, leaf length, tillers height, plant height, and whole plant height were observed for 12 weeks after planting (12 WAP).

\section{Results}

Table 1: Recapitulation of Analysis of Variance in Variables of Root Formation of Sipahutar Pineapple in 12 WAP

\begin{tabular}{|c|c|c|c|c|c|c|c|c|c|}
\hline \multirow[t]{2}{*}{ WAP } & \multicolumn{3}{|c|}{ Number of Roots } & \multicolumn{3}{|c|}{ Number of Leaves } & \multicolumn{3}{|c|}{ Number of Tillers } \\
\hline & M & IB & M\&IB & M & IB & M\&IB & M & IB & M\&IB \\
\hline 1 & td & td & td & $0.85^{\mathrm{tn}}$ & $1.97^{\text {tn }}$ & $0.28^{\mathrm{tn}}$ & $1,91^{\mathrm{tn}}$ & $0,48^{\mathrm{tn}}$ & $0,48^{\mathrm{tn}}$ \\
\hline 2 & $1^{\text {tn }}$ & $1^{\text {tn }}$ & $1^{\mathrm{tn}}$ & $2.78^{\mathrm{tn}}$ & $3.13^{\text {tn }}$ & $0.22^{\text {tn }}$ & $1,91^{\mathrm{tn}}$ & $0,48^{\mathrm{tn}}$ & $0,48^{\mathrm{tn}}$ \\
\hline 3 & $1,53^{\mathrm{tn}}$ & $0,92^{\mathrm{tn}}$ & $1,67^{\mathrm{tn}}$ & $0.75^{\text {tn }}$ & $3.12^{\text {tn }}$ & $0.81^{\text {tn }}$ & $1,35^{\mathrm{tn}}$ & $0,10^{\operatorname{tn}}$ & $0,85^{\mathrm{tn}}$ \\
\hline 4 & $1,13^{\mathrm{tn}}$ & $0,56^{\mathrm{tn}}$ & $1,93^{\mathrm{tn}}$ & $0.27^{\text {tn }}$ & $2.38^{\text {tn }}$ & $1.46^{\mathrm{tn}}$ & $0,38^{\text {tn }}$ & $0,54^{\mathrm{tn}}$ & $2,10^{\operatorname{tn}}$ \\
\hline 5 & $0,37^{\text {tn }}$ & $0,16^{\mathrm{tn}}$ & $2,01^{\mathrm{tn}}$ & $0.61^{\text {tn }}$ & $1.38^{\mathrm{tn}}$ & $1.43^{\text {tn }}$ & $0,37^{\text {tn }}$ & $0,16^{\mathrm{tn}}$ & $2,01^{\mathrm{tn}}$ \\
\hline 6 & $0,38^{\mathrm{tn}}$ & $0,15^{\mathrm{tn}}$ & $2,34^{\mathrm{tn}}$ & $0.85^{\text {tn }}$ & $0.28^{\text {tn }}$ & $2.06^{\mathrm{tn}}$ & $0,38^{\mathrm{tn}}$ & $0,15^{\mathrm{tn}}$ & $2,34^{\mathrm{tn}}$ \\
\hline 7 & $3,21^{*}$ & $1,66^{\mathrm{tn}}$ & $1,87^{\mathrm{tn}}$ & $0.97^{\text {tn }}$ & $0.07^{\text {tn }}$ & $1.98^{\text {tn }}$ & $0,15^{\text {tn }}$ & $2,34^{\mathrm{tn}}$ & $0,27^{\mathrm{tn}}$ \\
\hline 8 & $2,71^{\mathrm{tn}}$ & $0,90^{\operatorname{tn}}$ & $3,09^{*}$ & $1.06^{\mathrm{tn}}$ & $0.30^{\text {tn }}$ & $2.19^{\mathrm{tn}}$ & $0,08^{\mathrm{tn}}$ & $2,1^{\mathrm{tn}}$ & $0,3^{\text {tn }}$ \\
\hline 9 & $3,92^{*}$ & $1,48^{\text {tn }}$ & $3,25^{*}$ & $1.32^{\mathrm{tn}}$ & $0.33^{\text {tn }}$ & $2.71^{*}$ & $0,15^{\text {tn }}$ & $1,82^{\mathrm{tn}}$ & $0,3^{\text {tn }}$ \\
\hline 10 & $5,82^{* *}$ & $1,68^{\operatorname{tn}}$ & $3,89^{* *}$ & $1.38^{\mathrm{tn}}$ & $0.49^{\text {tn }}$ & $3.07^{*}$ & $0,15^{\mathrm{tn}}$ & $1,82^{\mathrm{tn}}$ & $0,3^{\text {tn }}$ \\
\hline 11 & $5,30^{*}$ & $1,63^{\mathrm{tn}}$ & $3,94^{* *}$ & $1.54^{\text {tn }}$ & $0.65^{\text {tn }}$ & $3.04^{*}$ & $0,15^{\text {tn }}$ & $1,82^{\mathrm{tn}}$ & $0,3^{\mathrm{tn}}$ \\
\hline 12 & $5,30^{*}$ & $1,63^{\mathrm{tn}}$ & $3,94^{* *}$ & $1.64^{\text {tn }}$ & $0.68^{\text {tn }}$ & $3.05^{*}$ & $0,3^{\text {tn }}$ & $0,15^{\mathrm{tn}}$ & $1,82^{\mathrm{tn}}$ \\
\hline WAP & Root I & & & Leaf L & & & Leaf $\mathrm{Y}$ & & \\
\hline \multirow[t]{2}{*}{12} & $5,33^{*}$ & $1,44^{\mathrm{tn}}$ & $1,24^{\mathrm{tn}}$ & $1,03^{\mathrm{tn}}$ & $1,87^{\text {tn }}$ & $2,59^{*}$ & $1,03^{\mathrm{tn}}$ & $0,40^{\mathrm{tn}}$ & $1,62^{\mathrm{tn}}$ \\
\hline & Tiller & & & Whole & t Heigh & & Plantle & & \\
\hline 12 & $1,18^{\mathrm{tn}}$ & $0,02^{\mathrm{tn}}$ & $2,92^{*}$ & $2,42^{\operatorname{tn}}$ & $1,72^{\text {tn }}$ & $6,88^{\text {tn }}$ & $1^{\text {tn }}$ & $1,42^{\text {tn }}$ & $1,72^{\mathrm{tn}}$ \\
\hline
\end{tabular}

Table 2: Average Number of Roots, Number of Leaves, Leaf Length and Tiller Height on the Observation of Root Formation of Sipahutar Pineapple in 12 WAP

\begin{tabular}{llll}
\hline Treatment & Number of roots & Number of leaves & Leaf length \\
\hline $\mathrm{M}_{0} \mathrm{IB}_{0}$ & $1.34 \pm 0.21 \mathrm{bc}$ & $9 \pm 6.24 \mathrm{abc}$ & $2.77 \pm 0.87 \mathrm{ab}$ \\
$\mathrm{M}_{0} \mathrm{IB}_{1,5}$ & $0.71 \pm 0.00 \mathrm{a}$ & $10 \pm 6.08 \mathrm{abcd}$ & $1.67 \pm 0.76 \mathrm{a}$ \\
$\mathrm{M}_{0} \mathrm{IB}_{3}$ & $1.76 \pm 0.31 \mathrm{~cd}$ & $2.67 \pm 0.58 \mathrm{a}$ & $5.03 \pm 0.15 \mathrm{~b}$ \\
$\mathrm{M}_{0,02} \mathrm{IB}_{0}$ & $0.88 \pm 0.29 \mathrm{ab}$ & $14 \pm 2.65 \mathrm{bcd}$ & $2.20 \pm 1.91 \mathrm{ab}$ \\
$\mathrm{M}_{0,02} \mathrm{IB}_{1,5}$ & $1.86 \pm 0.27 \mathrm{~d}$ & $12 \pm 8 \mathrm{abcd}$ & $0.71 \pm 0.0 \mathrm{a}$ \\
$\mathrm{M}_{0,02} \mathrm{IB}_{3}$ & $1.34 \pm 0.21 \mathrm{bcd}$ & $5 \pm 1 \mathrm{ab}$ & $0.75 \pm 0.08 \mathrm{a}$ \\
$\mathrm{M}_{0,04} \mathrm{IB}_{0}$ & $1.17 \pm 0.44 \mathrm{abc}$ & $7 \pm 5.29 \mathrm{abc}$ & $1.37 \pm 0.81 \mathrm{a}$ \\
$\mathrm{M}_{0,04} \mathrm{IB}_{1,5}$ & $1.73 \pm 0.89 \mathrm{~cd}$ & $9.33 \pm 3.51 \mathrm{abcd}$ & $2.67 \pm 2.08 \mathrm{ab}$ \\
$\mathrm{M}_{0,04} \mathrm{IB}_{3}$ & $1.56 \pm 0.33 \mathrm{~cd}$ & $21 \pm 14.80 \mathrm{~d}$ & $4.93 \pm 1.6 \mathrm{ab}$ \\
$\mathrm{M}_{0,06} \mathrm{IB}_{0}$ & $2.04 \pm 0.14 \mathrm{~d}$ & $20 \pm 5.29 \mathrm{~cd}$ & $3.5 \pm 2.18 \mathrm{ab}$ \\
$\mathrm{M}_{0,06} \mathrm{IB}_{1,5}$ & $1.86 \pm 0.27 \mathrm{~d}$ & $9.67 \pm 4.62 \mathrm{abcd}$ & $3.67 \pm 1.15 \mathrm{ab}$ \\
$\mathrm{M}_{0,06} \mathrm{IB}_{3}$ & $1.84 \pm 0.44 \mathrm{~cd}$ & $10 \pm 1.73 \mathrm{abcd}$ & $0.71 \pm 0.00 \mathrm{a}$ \\
Overall Mean & 18.07 & 207.00 & $0.88 \pm 0.29 \mathrm{ab}$ \\
$\mathrm{SD}$ & 3.80 & 61.75 & $1.64 \pm 0.84 \mathrm{c}$ \\
\hline
\end{tabular}

Description: mean \pm standard deviation of 3 replications, different letters showed significance in the 5\% DMRT test

Table 3: Observation Parameters of Time of Root Emergence, Time of Leaf Number Addition and Time of Tillers Emergence

\begin{tabular}{llll}
\hline Treatment & Time of root emergence (WPA) & Time of leaf number addition (WPA) & $5^{\text {th }}$ \\
\hline $\mathrm{M}_{0} \mathrm{IB}_{0}$ & $5^{\text {th }}$ & $5^{\text {th }}$ & $5^{\text {th }}$ \\
$\mathrm{M}_{0} \mathrm{IB}_{1,5}$ & - & $2^{\text {nd }}$ & - \\
$\mathrm{M}_{0} \mathrm{IB}_{3}$ & $4^{\text {th }}$ & $2^{\text {nd }}$ & $8^{\text {th }}$ \\
$\mathrm{M}_{0,02} \mathrm{IB}_{0}$ & $3^{\text {rd }}$ & $2^{\text {nd }}$ & $1^{\text {st }}$ \\
$\mathrm{M}_{0,02} \mathrm{IB}_{1,5}$ & $6^{\text {th }}$ & $2^{\text {nd }}$ & $1^{\text {st }}$ \\
$\mathrm{M}_{0,02} \mathrm{IB}_{3}$ & $5^{\text {th }}$ & $3^{\text {rd }}$ & - \\
$\mathrm{M}_{0,04} \mathrm{IB}_{0}$ & $3^{\text {rd }}$ & $4^{\text {th }}$ & $5^{\text {th }}$ \\
$\mathrm{M}_{0,04} \mathrm{IB}_{1,5}$ & $4^{\text {th }}$ & $1^{\text {st }}$ & $4^{\text {th }}$ \\
$\mathrm{M}_{0,04} \mathrm{IB}_{3}$ & $8^{\text {th }}$ & $3^{\text {rd }}$ & \\
$\mathrm{M}_{0,06} \mathrm{IB}_{0}$ & $5^{\text {th }}$ & $4^{\text {th }}$ & $3^{\text {rd }}$ \\
$\mathrm{M}_{0,06} \mathrm{IB}_{1,5}$ & $4^{\text {th }}$ & $3^{\text {rd }}$ & $5^{\text {th }}$ \\
$\mathrm{M}_{0,06} \mathrm{IB}_{3}$ & $4^{\text {th }}$ & $4^{\text {th }}$ & $9^{\text {th }}$ \\
\hline
\end{tabular}

The fastest root time appeared in the treatment of Myo-inositol concentration of $0.02 \mathrm{gr} / \mathrm{l}(\mathrm{M} 0.02 \mathrm{IB} 0)$ and the concentration of Myo-inositol $0.04 \mathrm{gr} / \mathrm{l}$ (M0.04IB0) was at week 3 after planting and at treatment of M0IB1.5. Leaf time appeared most rapidly in the treatment of single Myo-inositol with no IBA while the single influence of IBA there were treatments that did not appear the root from the first week until the last week was the treatment of IBA in $1 \mathrm{ppm}$. According to Febriyanti (2013) if the concentration of IBA given was too high, the time range of root appearance would be longer. This was evident in the treatment of $1.5 \mathrm{ppm}$ of IBA concentration, there were still explants that have no roots until the last day of the observation. 
The fastest growing leaf count was at treatment of M0.04IB1.5 with the concentration of Myo-inositol $0.04 \mathrm{gr} / 1$ with IBA of 1.5 ppm at age 1 WPA. The increase in the number of leaves on the fulfillment of the energy supply provided by Myo-inositol, this was in line with the study of Widiastoety (2012) suggested that the increase in the number of leaves affected by Myo-inositol plays a role in producing cell walls containing polysaccharides, protein, and lignin that can affect growth and development of the number of leaves.

The result of observation showed that the fastest sprout shoots appeared at treatment of M0.02IB1.5 and M0.02IB3 at age 1 WPA. When the buds appeared, marked with a white bulge which then became a green color then the actual shoots appeared. The faster the sprout shoots, the faster the resulting plant propagation material (Royani, 2015).

\section{Discussion}

\subsection{The effect of Myo-Inositol on the growth of Sipahu- tar pineapple plantlet}

The single factor of Myo-inositol had a significant effect on root number and root length. Myo-inositol with a $0.06 \mathrm{gr} / \mathrm{l}$ concentration was significantly affected with root number and Myo-inositol of $0.04 \mathrm{gr} / \mathrm{l}$ significantly affected root length

Table 4: The Influence of Myo Inositol on the Number of Roots and Root Length

\begin{tabular}{lll}
\hline \multirow{2}{*}{ Myo-inositol concentration $(\mathrm{gr} / \mathrm{l})$} & \multicolumn{2}{c}{ Mean } \\
\cline { 2 - 3 } & Root Number & Root Length \\
\hline 0 & $1.27 \mathrm{a}$ & $0.75 \mathrm{a}$ \\
0,02 & $1.36 \mathrm{a}$ & $0.76 \mathrm{a}$ \\
0,04 & $1.48 \mathrm{a}$ & $1.04 \mathrm{a}$ \\
0,06 & $1.91 \mathrm{a}$ & $0.78 \mathrm{a}$ \\
\hline Description: lowercase in numbers indicates the significance of Duncan Multiple Range Test
\end{tabular}

DMRT) test with 5\% confidence interval

Higher concentration of myo-inositol more optimally increasing the number of roots in Sipahutar pineapple, increasing the number of roots was also followed by the growth of buds on pineapple. This was in line with the research of Srilestari (2015), stated that the roots can grow if the planlet has produced new shoots and leaves. These new buds and leaves are expected to produce endogenous auxin and transcend it to the basal region and induce root formation.

Myo-inositol with a concentration of $0.04 \mathrm{gr} / \mathrm{l}$ showed the most favorable effect of other treatments. This result showed that Myoinositol with a concentration of $0.04 \mathrm{gr} / \mathrm{l}$ was good for stimulating root length. According to Widiastoety (2012), the addition of Myo-inositol with high concentration and in the right concentration could stimulate the growth of root length followed by the process of cell lengthening and enlargement. According to Loewus (2000), Myo-inositol and its metabolic compounds were indispensable in the growth and development of plants. The role of Myo-inositol in multiplication plants, Myo-inositol participates in phosphatidylinositol (PI) signaling pathways, storage and transport of auxin, phytic acid biosynthesis, cell wall biosynthesis, and stress-related molecular production. Keller (1998) also stated that Myo-inositol was a compound of poiliol (carbohydrates but not sugar) which is a precursor of plant metabolism, which plays a role in the signaling process. The given carbohydrate produces energy for the respiration process, as well as the material for forming new cells.

The documentation in Figure 3 showed the root length at the age of 12 WAP. The addition of root quantities and root lengths can also be influenced by basic media of MS + BAP $1 \mathrm{ppm}$ rich in minerals that stimulate the occurrence of cleavage also plays an important role in root growth so that roots increase in length (Karjadi, 2008). MS + BAP media can also increase shoot length and accelerate the appearance of roots (Khan, 2004). The specialty of the MS medium is the high content of nitrates, potassium and ammonium so it is very effective for the growth of some varieties of dicotyl and monocotyl plants (Isda, 2014). The use of Murashige \& Skoog (MS) basic media has a good influence on explant growth in tissue cultures of some plant varieties (Bella, 2016).

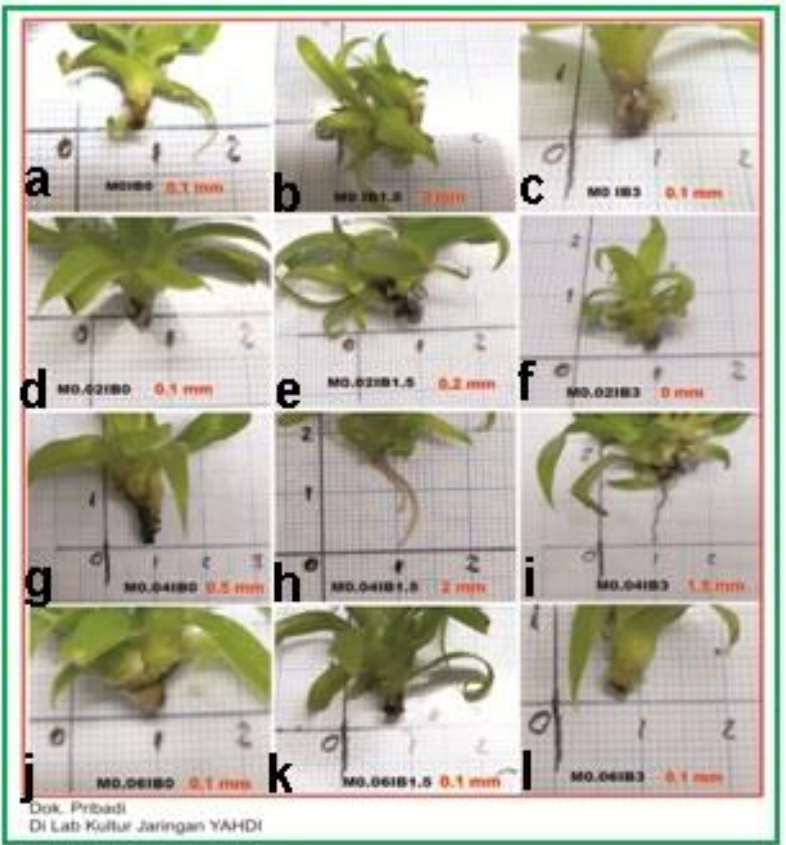

Fig. 3: Documentation of Root Length a. M0IB0 b. M0IB1.5 (No Root). c. M0IB3 d. M0.02IB0 e. M0.02IB1.5 f. M0.02IB3 g. M0.04IB0 h. M0.04IB1.5 i. M0.04IB3 j. M0.06IB0 k. M0.06IB1.5 1. M0.06IB3.

\subsection{The effect of Indol-3-Butyric-Acid (IBA) on the growth of planet Sipahutar pineapple}

In all observation parameters IBA, single factor did not give significant effects to pineapple explants. This may be due to dosage and treatment as well as environmental factors that resulted in the addition of IBA did not give the maximum effects on the growth of pineapple explants, whereas for root growth stimulated by IBA which is an effective growth regulator in stimulating root growth. According to Rugayah (2013), IBA is the most commonly used auxin type in stimulation of rooting compared with other auxin types, due to the high ability to initiate rooting (Arlianti, 2013). IBA has a more stable chemical content and longer working power so it can spur the formation of roots (Shofiana, 2013). One of the efforts that can be done to increase root development is the provision of the auxin (Karyanti, 2016).

However, the addition of auxin does not always increase the number of roots because the addition of certain types of auxin with a certain concentration can also decrease the number of roots (Rostiana, 2007). From the results of this research analysis noted that IBA did not influence to all parameters of observation, the main function of IBA as root growth stimulator did not give a good response. According to Febriyanti (2013), IBA has activity as a root hormone, so the activity of IBA can affect the number of roots. If IBA is given too high, it may inhibit root growth, it is also suspected that cytokinin of BAP $1 \mathrm{ppm}$ has been provided with too high concentration so that the addition of IBA with high concentrations may also inhibit root formation.

\subsection{The effect of Myo-inositol and Indole-3-Butyric-Acid (IBA) to the growth of Sipahutar pineapple plantlet}

From the result of observation showed that the interaction between Myo-inositol and IBA gave significant results to the number of roots, leaf number, leaf length and buds of Sipahutar pineapple.

The interaction of Myo-inositol with IBA had significant effect on root number, in Myo-inositol $0.06 \mathrm{gr} / \mathrm{l}$ treatment with IBA of 1.5 $\mathrm{ppm}$ and MS base medium plus $1 \mathrm{ppm}$ BAP. The combination of Myo-inositol of cytokines and auxins affected a significant num- 
ber of roots. Doses of too high auxin will disrupt the formation of roots, but at low or moderate doses will actually spur the formation of roots (Kartina, 2011).

Root formation is associated with endogenous auxin and cytokines content in plant tissue, followed by the process of elongation and cell enlargement. Myo-inositol is a carbohydrate compound although it is not a sugar in general in the right concentration that can stimulate rooting (Widiastoety, 2012). The rooting process is strongly influenced by the impermeability of the skin of the stem against water, with the ability of auxin (IBA) to break the hydrogen bond which can cause the auxin hormone to relax the epidermal cell wall, so that the epidermal cell wall expands. This can facilitate water into the stem. The entry of water into the stem will spur the process of rooting (Shofiana, 2013). IBA has better and more effective properties for adding rooted plant percentages, accelerating root growth, increasing root count, and improving root quality (Harahap, 2014).

The interaction of Myo-inositol with IBA had significant effects on the addition of leaf number. At the concentration of Myoinositol 0,04 gr/l with IBA given in $3 \mathrm{ppm}$ was the best concentration to stimulate the growth of pineapple leaf number. Increasing the number of leaves is one indicator of plant growth and can be used as supporting data to explain the growth process that occurred Arimarsetiowati (2012), leaves are one of the most important plant organs especially for photosynthesis so that plants can produce food and experience optimum growth.

One of the functions of IBA in leaf growth is to assist the development of prospective leaf meristem tissue. BAP $1 \mathrm{ppm}$ combined in MS base medium is known to have a very significant effect on the number of leaves. Similarly, research conducted by Mashud (2013), the use of growth regulators BAP or other endogenous cytokines, and growth regulators from the auxin group on growing media in vitro can affect the number of leaves and stimulate the growth and development of shoots in the later development of leaves.

The interaction of Myo-inositol with IBA had significant effects on leaf length at M0IB3 and M0.02IB1.5 treatment with the same average of 5.03 and continued at concentration M0.04IB1.5 with average leaf length of 4.93. Here is the leaf length documentation at the age of 12 WAP.

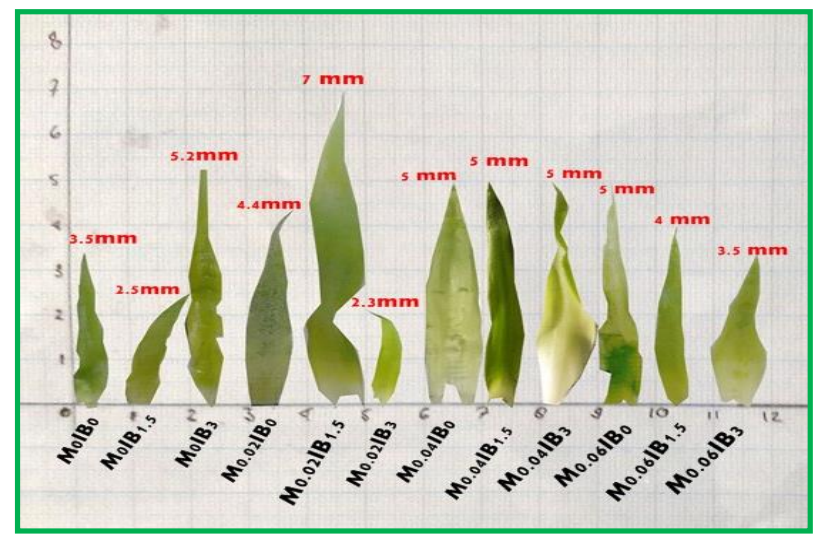

Fig. 2: Leaf Length Documentation on Various Myo-Inositol and IBA Treatments at Age 12 WAP.

Leaf length growth was influenced by a combination of IBA and Myo-inositol growing agents and BAP present in MS base medium. IBA growing regulators would not have a good effect if they were not combined with other growth regulators such as cytokines and other nutrients. This was in line with the study of Widiastoety (2012) stated that the process of growth and development of leaves in addition to requiring energy derived from the respiratory process also requires a number of hormones or growth regulators, such as auxin, cytokines and other nutrients contained in the growing medium. BAP of $1 \mathrm{ppm}$ combined in MS base medium is known to have a very significant effect on leaf length during the observation period (Santoso, 2013).
The interaction between Myo-inositol and IBA had an effect on tiller buds at Myo-inositol $0.04 \mathrm{~g} / \mathrm{l}$ with IBA of $3 \mathrm{ppm}$. Based on the research, the split plantlet showed the development of the sapling more rapidly than the complete plantlet, but did not show the significant increase of shoot number but the height and diameter of the sapling shoots. This is probably due to the effect of the treatment of Myo-inositol which plays a role in the deceleration of tissue growth and cell division so that the buds grow longer (Smart, 1993). According to Sepahvand (2012), different concentrations of Myo-inositol will have different effects on shoot growth. Myo-inositol with low concentration will affect the shoot height. In this case IBA also plays a role in promoting cell extension (cell elongation) by affecting cell wall metabolism. The effect resulted in many of the primary cell wall material being produced and deposited on the two ends of the cell, then the structural cells stretched to allow for more cell wall deposits. Thus, at the tip of the bud occurs cell extension (Mulyono, 2010). The following is a high documentation of the sapling of one of the replicates of each treatment at the age of $12 \mathrm{WAP}$.

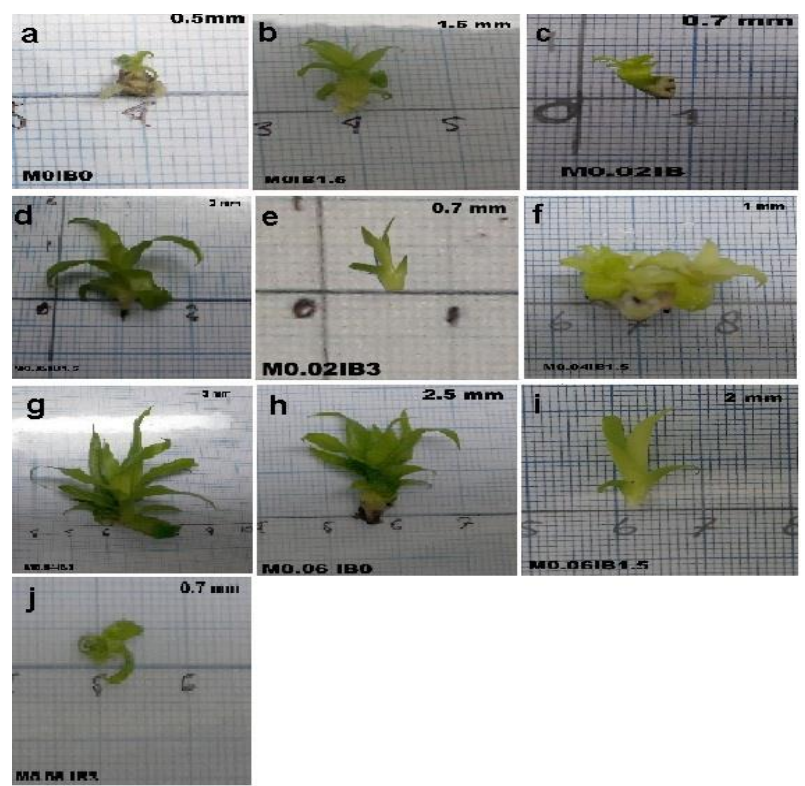

Fig. 3: Documentation of the Bud Height of Tillers a. M0IB0 b. M0IB1.5 c. M0.02IB0 d. M0.02IB1.5 e. M0.02IB3 f. M0.04IB1.5 g. M0.04IB3 h. M0.06IB0 i. M0.06IB1.5 j. M0.06IB3 While at Treatment M0IB3 and M0.04IB0 Have No Bud.

From the observation showed that Myo-inositol $0.04 \mathrm{~g} / \mathrm{l}$ and IBA $3 \mathrm{ppm}$ did not have buds this may be due to the addition of cytokines-growth substances that was too high in MS base medium so that it could inhibit the high growth of buden explant tillers. According to Wicaksono (2016), cytokines in high numbers will inhibit the number of tillers but cytokines combined with auxin can function to increase the height of the seedling buds in the plant.

According to Paramartha (2012), the combination of growth regulators auxin and cytokines affects the growth of explants. If the ratio of cytokines and auxin are relatively balanced then the explant will form a meristematic cell mass and continue to grow. When auxin concentration is higher than cytokines, there will be root formation. On the other hand, when the auxin concentration is lower than cytokines it will occur shoot regeneration (Zulkarnain, 2017). Similarly, according to Rugayah (2015) stated that the formation of shoots in vitro is influenced by the presence of high cytokines in the culture medium, and the most effective type of cytokines is BAP. Cytokines concentration is higher than auxin concentration in culture medium will inhibit root growth and will precisely stimulate shoot formation. IBA and BAP both that have been widely used in in vitro cultures (Cerianingsih, 2015).

Myo-inositol and Indole-3-Butiric-Acid (IBA) had no effect on the observed parameters of shoot number, leaf width, plant height or whole plant height as well. It is suspected that the addition of aux- 
in (IBA) level may affect the increase of plant height but the excess amount of auxin will be transransferred to the base for root formation resulting in increased plant growth (Mulyono, 2010). Likewise, the observation parameters of the shoot number of Myoinositol and IBA did not give a real effect; this possibility is due to the factor of poor treatment concentration that tends to increase the growth of shoot height. According to Ramesh and Ramassamy (2014), if fewer buds number is produced then the higher shoot size of the tillers is higher, and vice versa.

Myo-inositol and IBA also had no significant effect on leaf width. This is probably because the concentration factor or dose given is unbalanced so that Myo-inositol and IBA only affect the number of leaves and leaf length. According to Gunawan (1992), stated that with the balance between exogenous growth regulator auxin and cytokines are able to stimulate the formation of organs, in addition the formation of organs is also determined by the balance of plant growth regulator in the plant tissue.

\section{Conclusion}

The addition of nutrients Myo-inositol could stimulate the growth of the number of roots and lengths. Indole-Butyric Acid (IBA) growth regulators provide a less epic root growth response in stimulating growth in the number or length of the pineapple roots. The main function of IBA was inhibited or quitted because the administration of BAP cytokines of $1 \mathrm{ppm}$ on MS medium was too high. Meanwhile, Myo-inositol and IBA interactions significantly affected the number of roots, leaf number, leaf length and shoot height of Sipahutar pineapple explant. However, Myoinositol and IBA had no significant effects on the number of buds, leaf width, plantlet height or height of whole Sipahutar pineapple explant as well. Suggestion: Further research is needed to determine the more appropriate concentration for rooting of Sipahutar Pineapple.

\section{Acknowledgements}

The authors would like to thank the Yahdi tissue culture laboratory, the education program of Postgraduate Biology of Universitas Negeri Medan which has supported the implementation of this research.

\section{References}

[1] Anonim. 2015 http:/ /hariansib.co /view/ Marsipature Hutanabe/44107/Petani-Sipahutar-Butuh-Bibit-Nenas.html.

[2] Anonim. 2016). http: //www. Medanbis nisdaily.com/new s/read/2016/06/02/237611/nenas-taput-nyeberang-ke-malaysia/.

[3] Anonim. 2007). https:// www.merdeka. com/uang/dikaleng-nanastapanuli-utara-tembus-ekspor-sizqtx $2 . \mathrm{html}$.

[4] Arlianti T, Syahid S, Kristina N, dan Ros O. 2013. Pengaruh Auksin IAA, IBA, Dan NAA Terhadap Induksi Perakaran Tanaman Stevia (Stevia Rebaudiana) Secara in Vitro. Bul. Littro, 24(2): 57 62.

[5] Arimarsetiowati, R. dan Ardiyani, F. 2012. Pengaruh penambahan auxin terhadap pertunasan dan perakaran kopi arabika perbanyakan Somatik Embriogenesis. Pelita Perkebunan, 28(2): 82 - 90.

[6] Bella. Suminar, E. Nuraini, A. 2016. Pengujian efektivitas berbagai jenis dan konsentrasi sitokinin terhadap multiplikasi tunas mikro pisang (Musa paradisiaca L.) secara in vitro Jurnal Kultivasi, 15(2): $74-80$.

[7] Cerianingsih M. W, Astarini I. A dan Nurjaya I. G. O. 2015. Pengaruh Kombinasi Zat Pengatur Tumbuh Indole-3-Butyric Acid (IBA) Dan 6-Benzil Amino Purin (BAP) Pada Kultur in Vitro Tunas Aksilar Anggur (Vitis vinifera L.) Varietas Prabu Bestari Dan jestro Ag 86. Jurnal Metamorfosa, 2 (1): 1 - 8.

[8] Duval MF, Noyer JL, Perrier X, Coppens d'Eeckenbrugge G, Hamon P (2001). Molecular diversity in pineapple assessed by RFLP markers. Theor. Appl. Genet.102: 83-90. https://doi.org/10.1007/s001220051621.

[9] Febriyanti E, Suwirmen dan dris M. 2013 Induksi Perakaran Tunas Tetrastigma rafflesiae Miq. Pada Media Murashige-Skoog Dengan
Penambahan Beberapa Konsentrasi Indole-3-Butyric Acid (IBA) secara In Vitro. Jurnal Biologi Universitas Andalas, 2(3): $188-$ 193.

[10] Febriyanti. 2017. Induksi pertumbuhan tuna's dari eksplan anggrek Dendrobium Heterocarpum Lindl. Dengan pemberian hormon zeatin dan NAA. Jurnal Metamorfosa, 4 (1): 41 - 47.

[11] Gunawan, L. W. 1992. Teknik Kultur Jaringan Tumbuhan. Departemen Pendidikan dan Kebudayaan. DIKTI - PAU IPB, Bogor.

[12] Harahap, F. 2011. Kultur Jaringan Tanaman. Medan : Unimed Press.

[13] Harahap, F dan Nusyirwan. 2012. Induksi Pertumbuhan Nanas (Ananas comosus L.) In Vitro Asal Pangaribuan dengan Pemberian Zat Pengatur Tumbuh Kinetin. Prosiding Semirata BKS PTN-B MIPA : "Peranan MIPA Dalam Pengembangan SDM dan SDA. Hotel Madani-Universitas Negeri Medan.

[14] Harahap, F., Hasruddin, Suriani, C., Nusyirwan, Siallagan, J. dan Rohyana. 2013. Sterilisasi Eksplan Nanas (Ananas comusus L.) Asal Sipahutar dan Induksi Pertumbuhan dengan Perlakuan Benzil Amino Purin dan Indole Acetic Acid Secara In Vitro. Seminar Nasional ke-22 Perhimpunan Biologi Indonesia. Purwokerto, Jawa Tengah.

[15] Harahap, F dan Nusyirwan. 2014. Induksi Tunas Nanas (Ananas comusus L. Merr) In Vitro dengan Pemberian Dosis Auksin dan Sitokin yang Berbeda. Jurnal Saintika, 15(11) : 124-131.

[16] Harahap, F., Poerwanto, R., Suharsono, Suriani, C., \& Rahayu, S. 2014. In Vitro Growth and Rooting of Mangosteen (Garnicia mangostana L.) on Medium with Different Concentration of Plant Growth Regulator. Hayati Journal of Bioscience, 21(4) : 151-158. https://doi.org/10.4308/hjb.21.4.151.

[17] Harahap, F., Poerwanto, R., Sobir, Hasruddin, Suriani, C., Siallagan, J \& Rohyana. 2015. Sterilization of Pineapple Explant From Sipahutar, North Sumatera, Indonesia (Ananas comosus L.) and In Vitro Growth Induction. Asian Jr. Of Microbiol. Biotech, $17(2): 469-478$.

[18] Heriansyah, P. 2014. Pengaruh Pemberian Myo-inositol Dan Arang Aktif Pada Media Sub Kultur Jaringan Tanaman Anggrek (Dendrobium Sp) Jurnal Agroteknologi, 5 (1) : 9 - 16

[19] Idowu, A, E, P. Akinyemi, S, O, S. and Ibitoye, O, D. 2014. Influence of medium type and growth regulators on in vitro micropropagation of pineapple (Ananas comosus (L.), var. Smooth cayenne) African Journal of Plant Science, 8(9): 450-456.

[20] Kartina. Nurmayulis dan Susiyanti. 2011. Pengaruh indole butiric acid (IBA) terhadap Pembentukan akar pada tanaman aren. $J$. Agrivigor, 10(2): 208-218.

[21] Khan S, Nasib A, Saeed BA (2004). Employment of in vitro technology for large-scale multiplication of pineapples (Ananas comosus). Pak. J. Bot, 36(3): 611 - 615.

[22] Keller, R., Brearley, C., Trethewey, R., and Muller-Rober, B. (1998) Reduced inositol content and altered morphology in transgenic potato plants inhibited for 1D-myoinositol 3-phosphate synthase. The Plant Journal. 16:403 - 410. https://doi.org/10.1046/j.1365-313x.1998.00309.x.

[23] Loewus, F. and Murthy, P. (2000) Myo inositol metabolism in plants. Plant Science. Elsevier Science. 150:1-19.

[24] Mashud, N. 2013. Efek Zat Pengatur Tumbuh BAP Terhadap Pertumbuhan Planlet Kelapa Genjah Kopyor dari Kecambah yang Dibelah Balai Penelitian Tanaman Palma, 14 (2): 82 - 87

[25] Mulyono, D. 2010. Pengaruh Zat Pengatur Tumbuh Auksin: Indole Butiric Acid (IBA) dan Sitokinin: Benzil Amino Purine (BAP) dan Kinetin dalam Elongasi Pertunasan gaharu (Aquilaria beccariana). Jurnal Sains dan Teknologi Indonesia, 12 (2): 1 - 7.

[26] Paramartha, I, A. Ermavitalini, D dan Nurfadilah, S. 2012 Pengaruh Penambahan Kombinasi Konsentrasi ZPT NAA dan BAP terhadap Pertumbuhan dan Perkembangan Biji Dendrobium Taurulinum J.J Smith Secara in Vitro. Jurnal Sains Dan Seni Its, 1 (1): $40-43$.

[27] Ramesh, Y., and V. Ramassamy. 2014. Effect of gelling agents in in vitro multiplication of banana var. Poovan. Int. J. Advanced Bio. Research 4(3): 308 - 311

[28] Rostiana, O. dan Seswita, D. 2007. Pengaruh Indole Butyric Acid DAN Naphtaleine Acetic Acid Terhadap Induksi Perakaran Tunas Piretrum [Chrysanthemum cinerariifolium (Trevir.)Vis.] Klon Prau 6 Secara in Vitro. Bul. Littr, 18 (1): 39 - 48.

[29] Royani, I. Zulkifli, L. dan Sedijani P. 2015. Regenerasi Tunas Dan Akar Dari Kalus Daun Kacang Tanah (Arachis hypogaea L.) Varietas Kelinci Dengan KombinasI 2, 4-D dan BAP.

[30] Rugayah, Anggalia I, Ginting C, Y. 2013. Pengaruh Konsentrasi Dan Cara Aplikasi IBA (Indole Butiric Acid) Terhadap Pertum- 
buhan Bibit Nanas (Ananas comosus [L.] Merr.) Asal Tunas Mahkota. Jurnal Agrotropika, 17(1): 35-38.

[31] Santoso, D, R. dan Sobir. 2013 Pertumbuhan Planlet Nenas (Ananas comosus L. Merr.) Varietas Smooth Cayenne Hasil Kultur in Vitro pada Beberapa Konsentrasi BAP dan Umur Plantlet. Bul. Agrohorti, 1 (1): 54 - 61

[32] Sepahvand, S. Ebadi A. Kamali K. Ghaemmaghami S.A. 2012. Effects of Myo-Inositol and Thiamine on Micropropagation of GF677 (Peach $\times$ Almond Hybrid) Journal of Agricultural Science, 4 (2): $275-280$.

[33] Srilestari, R dan Sasmita, R, E. 2015. Perbanyakan pisang raja bulu secara in vitro dengan menggunakan pupuk daun. Agrivet, 19: 1-6.

[34] Shofiana A, Rahayu Y, Lukas S. Budipramana. 2013. Pengaruh Pemberian Berbagai Konsentrasi Hormon IBA (Indole Butyric Acid) terhadap Pertumbuhan Akar pada Stek Batang Tanaman Buah Naga (Hylocereus undatus). LenteraBio, 2 (1):101-105.

[35] Sitorus, N. Hastuti, E dan Setiari, N. 2011. Induksi Kalus Binahong (Basella rubra L.) Secara in Vitro Pada Media Murashige \& Skoog Dengan Konsentrasi Sukrosa Yang Berbeda. BIOMA, 13 (1): 1 -7.

[36] Smart, C.C. and Fleming, A.J. (1993) a plant gene with homology to D-myo-inositol-3-phosphate synthase is rapidly and spatially up regulated during an abscisic-acid-induced morphogenic response in Spirodela polyrrhiza. Plant J, 4: 279 - 293. https://doi.org/10.1046/j.1365-313X.1993.04020279.x.

[37] Syafii M, Badami K, Nursandi F. 2013. Pengaruh indol-3-butiricacid dan Thidiazuron Terhadap Multiplikasi Tunas Nenas (ananas comosus (1) merr) cv. Smooth cayyene secara in vitro. Jurnal Rekayasa, 6 (1) 614

[38] Widiastoety. A, Santi. dan N, Solvia. 2012. Pengaruh Myo-inositol dan Arang Aktif terhadap Pertumbuhan Planlet Anggrek Dendrobium dalam Kultur in Vitro. J. Hort. 22(3): 205-209 https://doi.org/10.21082/jhort.v22n3.2012.p205-209.

[39] Yusnita. 2004. Kultur Jaringan Cara Memperbanyak Tanaman Secara Efisien. PT Agromedia pustaka.

[40] Zulkarnain and Neliyati. 2017. The Effect of NAA and BAP on Tissue Culture of Tangkit Pineapple (Ananas comosus (L.) Merr. cv. Tangkit). Biospecies, 10 (1) : 1-10.

[41] Wicaksono, F. Y. T. Nurmala, A.W. Irwan, A.S.U. Putri. 2016 Pengaruh pemberian gibberellin dan sitokinin pada konsentrasi yang berbeda terhadap pertumbuhan dan hasil gandum (Triticum aestivum L.) di dataran medium Jatinangor. Jurnal Kultivasi, 15(1):52 -58. https://doi.org/10.24198/kltv.v15i1.12004. 